\title{
Interdisciplinary Primary School Curriculum Units for Sustainable Development
}

Eli Munkebye', Eldri Scheie ${ }^{2}$, Stig Misund ${ }^{3}$, Anja Gabrielsen ${ }^{4}$, Anne Bergljot Øyehaug 5 , Arne Jordet $^{6}$, and Tone Nergård ${ }^{7}$

\author{
${ }^{1}$ Norwegian University of Science and Technology, NTNU, Trondheim, Norway \\ ${ }^{2}$ Norwegian Centre for Science Education. University of Oslo, Norway \\ ${ }^{3}$ The Arctic University of Norway, UiT, Alta, Norway \\ ${ }^{4}$ University College of Southeast Norway, Porsgrunn, Norway \\ ${ }^{56}$ Inland Norway University of Applied Sciences, Hedmark,Norway \\ ${ }^{7}$ Nord University, Levanger, Norway
}

\begin{abstract}
Education for sustainable development (ESD) provides crucial opportunities for young people to be involved in complex sustainability issues. This study contributes to existing knowledge about primary school teachers' approaches to ESD across a range of subjects. Norwegian schools can join the Sustainable Backpack programme (SBP), which supports teachers to develop projects that promote a holistic understanding of sustainable development across school subjects. The present study set out to examines teachers' interdisciplinary approach to ESD and the SBP teachers' perceptions of how their curriculum units promote environmental, social and economic dimensions of sustainable development. The study is a multi-case study, with curriculum units designed for students aged 10-13 years from 14 Norwegian schools. Content analysis suggest that the units used several subjects to ESD, but the teachers could have challenged the students' reflection to a greater extent in terms of argumentation and critical thinking. The units succeeded to some extent in pursuing a holistic approach.
\end{abstract}

\section{Sustainable Development}

In pursuing the goals of sustainable development (SD), the United Nations has focused its efforts on improving social conditions, solving environmental problems and reducing 
economic inequality, implying an interaction between environmental, social and economic dimensions, now and in the future (UNESCO, 2006).

With its geographical location and long coastline, Norway has large natural resources such as oil, natural gas, hydropower, fish and metals, and these dominate the country's exports (Statistics Norway, 2020). These natural resources also play a key role in Norway's sustainability challenges, where the largest is the contribution to continued availability and use of oil and natural gas resources which will result in increased greenhouse gas emissions. There are major conflicts of interest and sustainability challenges, in the continued development of renewable energy sources such as hydropower and wind power, as this adversely affects natural areas, ecosystem and biodiversity.

Both in Norway and internationally there is growing understanding that SD requires a holistic approach that treats all three dimensions as equally important and intertwined (Corney, 2006; Dale \& Newman, 2005; De Haan, 2006; Koppelman, 2010; Summers \& Childs, 2007; UNESCO, 2005; Van den Bergh, Atkinson, Dietz, \& Neumayer, 2007). A holistic approach should also address the interrelationships between these dimensions in time and space (Wals, 2012), referring respectively to the past, present and future and to the local and distant geographic relationships within a global context.

\section{Education for Sustainable Development}

Education for sustainable development (ESD) refers to the integration of key sustainability issues into teaching and learning (UNESCO, 2017, p. 9) to provide opportunities for young people to acquire first-hand experience in addressing the socio-ecological challenges faced by their communities. ESD is widely understood as "education which empowers learners to make informed decisions and responsible actions for environmental integrity, economic viability and a just society, for present and future generations, while respecting cultural diversity" (UNESCO, 2014, p. 12). This means developing individual and societal knowledge, skills, attitudes and values that will enable people to live and work in a sustainable way (Rickinson, Lundholm, \& Hopwood, 2009). Despite wide variations within ESD and in the design of ESD projects in schools, there is a general consensus that the goal of ESD is to develop competencies that empower individuals to act (UNESCO, 2017, p. 7). Vare and Scott (2007) discuss two complementary approaches to ESD: learning for SD 
(ESD1) and learning as SD (ESD2). ESD1 'means raising awareness of the need to change and facilitate changes in what we do, and its effects can be measured by reduced environmental impact. ESD2 includes ESD as the first loop and adds a second loop. The second loop is meant to build critical competence, to encourage learning as a collaborative and reflective open-ended process and to prepare individuals to meet future challenges. The effects of ESD2 can be measured by the extent of individuals' motivation, informedness, abilities to be critical and empowerment.

Norway responded to the United Nations' Decade of Education for Sustainable Development 2005-2014 (UNESCO, 2005) by developing two strategic plans for ESD, one for the period of 2006-2010 (Utdanningsdirektoratet, 2006) and another for the period of 2012-2015 (Kunnskapsdepartementet, 2012). However, a national survey in 2011 found that only $9 \%$ of the Norwegian school leaders felt inspired to change their teaching practices as a result of the Decade of Education for Sustainable Development (Vibe, 2012). While 58\% said they were interested in SD-related issues, only $27 \%$ said that they had sufficient ESD competencies at their school (Vibe, 2012). This finding aligns with the stated need in the Norwegian strategy for ESD 2012-2015 (Kunnskapsdepartementet, 2012) to educate teachers in ESD. ESD is challenging for teachers, not least because of the interdisciplinary nature of contemporary sustainability issues (WCED, 1987). Because real-world SD is complex, ESD must incorporate perspectives and methods from a range of school subjects and is not suited to conventional didactic approaches based on individual and separate subjects.

To address these issues, a Norwegian committee was established in 2013 to consider basic education needs for ensuring future competence in society and working life. In the committee's second report, ESD was highlighted as one of the three key interdisciplinary topics for the school of the future (Kunnskapsdepartementet, 2015). This was followed by a new core curriculum that challenges the existing education system by calling for crosscurricular teaching to address three interdisciplinary themes: 1) sustainable development, 2) democracy and participation (citizenship) and 3) public health and wellbeing (Kunnskapsdepartementet, 2016). 
Definitions of multidisciplinary and interdisciplinary teaching and learning are varied, sometimes conflicting and sometimes too abstract to be applicable to the everyday practices of teachers and students (e.g. Boix-Mansilla \& Duraisingh, 2007). In this study, we see interdisciplinary teaching as the integration and interaction of subjects involved in solving a shared problem. Teachers from different subjects have to coordinate and collaborate in this problem-solving process in their teaching. While multidisciplinary approaches draw on knowledge from various disciplines that remain within their boundaries, interdisciplinarity analyses synthesise and harmonise the interrelated disciplines into a coordinated and coherent whole.

The interdisciplinary nature of SD requires teachers from different subjects to collaborate across the curriculum and to teach across subject boundaries. In practice, many teachers face challenges when teaching SD (Borg, Gericke, Høglund, \& Bergman, 2012; Pharo et al., 2012). The main challenge is that SD is an interdisciplinary topic, in contrast to traditional school subjects, which are generally monodisciplinary. Teachers who collaborate with their colleagues across disciplines in interdisciplinary education report being overworked and unable to dedicate the necessary time to plan interdisciplinary curriculum units (Gayford, 2002; Sjøberg, Jorde, Haldorsen, \& Lea, 1995). The result is that the teachers who teach interdisciplinary topics tend to maintain the integrity of their subject or neglect the subject areas beyond their main expertise (Pharo et al., 2012).

In Norway, interdisciplinary work has been part of the curricula for the past 80 years. In the curriculum of 1997 (L97), the scope of theme- and project-based work was given a minimum standard: $60 \%$ of the classroom time for the youngest students and $20 \%$ for the rest. In policy documents, theme-based work was defined as interdisciplinary, while projectbased work was defined as both interdisciplinary and subject-based (Solstad, Rønning, \& Karlsen, 2003). Solstad et al. (2003) pointed out that the social sciences and natural and environmental sciences were treated by the teachers as most suitable for theme- and projectbased work, while the Norwegian language subject was referred to as a tool for writing and reading for learning. The practical-aesthetic subjects often have their own subject teachers, which was considered to be an obstacle for interdisciplinary collaboration. Research on the implementation of the Knowledge Promotion (the education reform introduced in 2006 for primary, lower secondary and upper secondary education and training) has shown that 
schools have worked less with interdisciplinary themes after the implementation, than under former Norwegian school curricula reforms (Hodgson, Rønning, \& Tomlinson, 2012; Imsen \& Ramberg, 2014). Furthermore, it has been shown that schools have prioritised competence aims in the subject curriculum and basic skills rather than holistic and interdisciplinary work (Imsen \& Ramberg, 2014).

\section{The Sustainable Backpack Program}

In response to the Decade of Education for Sustainable Development and the Norwegian strategic plan for ESD for the period of 2006-2010 (Utdanningsdirektoratet, 2006), the Sustainable Backpack program (SBP) was initiated by the Ministry of Education and Research and the Ministry of Climate and Environment (Figure 1). Targeting Norwegian primary, secondary and upper secondary schools, the SBP's aim is to increase SD-related awareness, understanding and competencies among teachers and students (Scheie \& Stromholt, 2019).

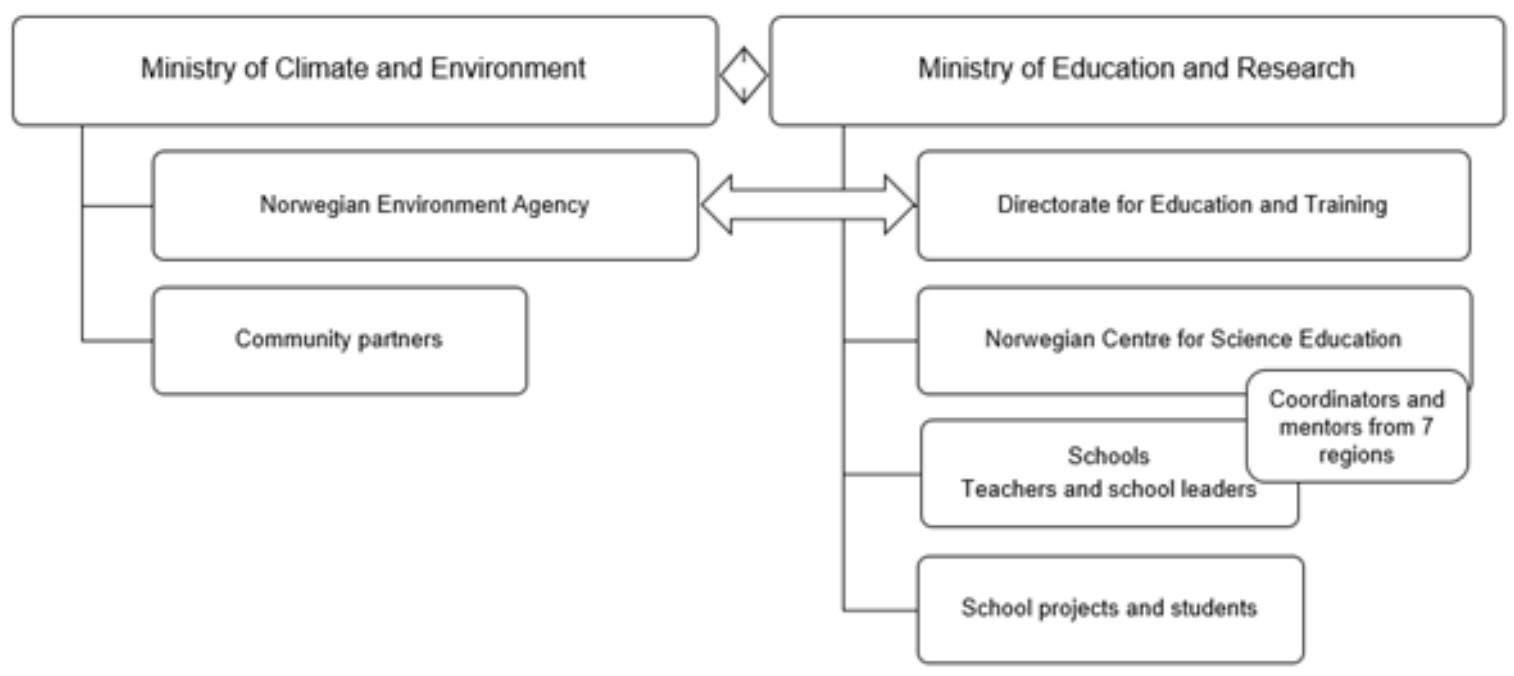

Figure 1. Organisation of SBP (Scheie \& Stromholt, 2019:4).

Through the SBP, schools can apply for financial and professional teacher training support to develop and implement SD curriculum units in the classroom. By attending regional and national SBP meetings, teachers become part of a professional ESD learning community. Schools must in their curriculum units include at least two subjects, and natural science or 
social studies must be one of them. There is no limit to how many subjects schools can include. SBP curriculum units are required to adopt a multidisciplinary approach.

Additionally, a central focus for schools in the SBP has been both to use authentic and concrete issues from students' local environment and to collaborate with external partners or community organisations (Scheie \& Stromholt, 2019). Scheie and Stromholt (2019) found that teachers reported on the project's influence on their practice beyond the project, with many feeling that their teaching had become more varied and more relevant to students' everyday lives as the teachers were more likely to use different settings.

Schools are invited to apply to participate in the SBP, and each year around 140 schools are accepted. The selected schools (with at least two teachers for each school) are encouraged to participate for three years. Each school receives about 6,000 euros to cover the teachers' participation in various initiatives to enhance their competence and to plan their teaching. Teachers must participate in an annual conference and two regional meetings each year.

Regional meetings are chaired by teacher educators who act as mentors to improve teachers' scientific and pedagogical competence. The application entails the development of a curriculum unit for groups of students. At the regional meetings, teachers from different schools collaborate, exchange feedback and receive feedback from their mentors. Therefore, the meetings serve as a learning network for professional development.

Teachers must deliver two reports during the year that describe and justify their curriculum unit, and this is followed by guidance from their mentors. An external evaluation of the SBP in 2013-2014 (Sjaastad, Carlsten, Opheim, \& Jensen, 2014) with 667 student respondents and 192 schoolteacher respondents, indicated that students involved in the project had increased SD-related knowledge, attitudes and skills.

\section{Research Question}

This study follows up on a recent multi-case study of SBP projects for primary school students (aged 6-9 years), which investigated the contributions of different subjects to ESD (Munkebye, 2016). The results indicated that natural science and social studies directly supported the projects' overarching aim to help students achieve sustainability consciousness. The Norwegian language subject and mathematics supported these aims by being tools for the students. For example, in the Norwegian language subject, students 
should learn to use a suitable vocabulary to talk about academic topics, share their own experiences and express their own opinions. These competence aims are not directed towards the overarching aim but help the students achieve them.

ESD can be perceived as challenging for teachers because it requires an interdisciplinary approach. The aim of this study was to understand how teachers combined aims in ESD curriculum units and teachers' perceptions of how the curriculum units promoted students' understanding of SD. The following research questions were addressed:

RQ1: How are subjects and competence aims combined in ESD curriculum units for students aged $10-13$ years?

RQ2: How do teachers perceive the curriculum units promoting students' understanding of the three dimensions of SD?

\section{Research Design and Method}

The study had a flexible design (Robson, 2002) and used qualitative methods, with the problems, theoretical framework, methods and interpretation of the results having been developed along the way. Case studies are a system bound in time and space, where the focus of the study can be an activity, an individual, an event or a social entity rather than a process (Stake, 1995). This study is categorised as a multi-case study (Yin, 2003), with curriculum units being the cases. Where multiple cases are examined, each case is often described based on the themes specific to the case or context, and a cross-case analysis is often included based on the themes common to the cases studied (Creswell, 1998). As Stake (1995) pointed out, one cannot always understand a case without referring to other cases. Rather than pursuing explanations as analytical studies do, our study is descriptive; as opposed to normative studies, it describes how things are rather than how they should be (Robson, 2002). It is important to be aware that these cases provide no basis for statistical generalisation (Robson, 2002).

The selection of 14 curriculum units can be categorised as convenience sampling, with access to supplementary information being crucial (Robson, 2002). The curriculum units were developed by the respective teachers, with guidance from the SBP mentors. The 
sample is taken from 10 out of a total of 18 counties in Norway. The curriculum units were designed for 5th- to 7th-grade students. All the schools had participated in the SBP for 3-4 years (including ESD-related professional development and guidance).

\section{Data Collection and Analysis}

The data were collected from teachers' final reports describing the curriculum units from the last three years. Final reports were based on a template (Table 1). When necessary, teachers were contacted for clarification.

Table 1. Excerpts from the Template for the Final Report

\begin{tabular}{|l|}
\hline Inter- and multi-disciplinary work: Describe the subjects that are part of the project. \\
\hline Competence aims from the curriculum. \\
\hline ESD: It describes the ways in which the teaching program helps to promote students' understanding of SD. \\
\hline The curriculum unit: Describe the methods, teaching and student activities.
\end{tabular}

Content analysis was used to analyse the reports (Castleberry \& Nolen, 2018). In all reports, the applied competence aims were ticked off, and summarised (see Table 2-5). The analysis of the teachers' accounts of how the curriculum units promoted students' understanding of SD revealed different levels of description, ranging from what the students had done or learned to teachers' reflections about students' learning. The following is an example of a teacher's reflection: "The fact that we discussed global warming and its causes caused students to reflect on how they themselves, through their choices, affect both pollution and global warming." Because the curriculum units were designed for young students, we analysed the reports by identifying statements indicating engagement with the three dimensions of SD. For example, a statement such as "we focused on human influences" was categorised as social; "students discussed cultivation in relation to altitude" was categorised as environmental; and "assessing the prices of products with different packaging" was categorised as economic.

Two of the authors have completed all the analyzes. The analyzes were then compared, and where they did not coincide, these were negotiated for a common interpretation. 


\section{Study Context}

The school cases are represented by 10 counties (out of a total of 18 county in 2019), with 6 of the school cases being in the northern part of the country and 8 in the southern part. Table 2 summarises the curriculum units developed by the respective teachers from the schools participating in the SBP.

Table 2. Short Descriptions of Curriculum Units

\begin{tabular}{|c|c|c|}
\hline Case & Grade & Short Descriptions of Curriculum Units (with Activities in Parentheses) \\
\hline 1 & 5 th -7 th & $\begin{array}{l}\text { The students explored a local river and developed knowledge about its annual cycle, } \\
\text { biodiversity and human impacts (made a movie; ice fishing). }\end{array}$ \\
\hline 2 & 5 th -7 th & $\begin{array}{l}\text { The school is located in the north, close to the Russian border. Students gained } \\
\text { insights into the Sami way of life. By visiting protected areas, students learned about } \\
\text { the biodiversity and the fragility of living organisms in this harsh environment. They } \\
\text { also explored restrictions in similar areas in Russia and Finland (model of Sami } \\
\text { settlement). }\end{array}$ \\
\hline 3 & 5 th -7 th & $\begin{array}{l}\text { The school is located near salmon-rich rivers. The students adopted a salmon and } \\
\text { trout spawning stream and improved the conditions for fish in and along the stream } \\
\text { to increase spawning activity (salmon meal; report). }\end{array}$ \\
\hline 4 & 5 th -7 th & $\begin{array}{l}\text { The school is located on an island with unique geology. Students reflected on the } \\
\text { effects of facilitating geological tourism. The project focused on the students' } \\
\text { understanding of how their community can sustain itself in the future (stone } \\
\text { exhibition; newspaper article). }\end{array}$ \\
\hline 5 & 5 th -7 th & $\begin{array}{l}\text { The project addressed how plastics pollute the local lake and what students can do to } \\
\text { reduce the consumption of plastics (diagrams; made shopping bags; argumentative } \\
\text { text). }\end{array}$ \\
\hline 6 & 5 th -7 th & $\begin{array}{l}\text { By hunting and harvesting, students used natural resources to reflect on short- } \\
\text { travelled traditional food. They prepared a school garden, participated in elk hunting } \\
\text { and made produce from these activities (meals; interviews; debate). }\end{array}$ \\
\hline 7 & 5 th -7 th & $\begin{array}{l}\text { Students grew and harvested their own herbs and vegetables on a small farm near the } \\
\text { school. They discussed how seeds can contribute to local and global food production } \\
\text { (made posters, meals and books). }\end{array}$ \\
\hline 8 & 5 th -7 th & $\begin{array}{l}\text { To explore and learn about the coastal community's rich history, students mapped } \\
\text { the flora and fauna in different coastal zones and picked and recorded marine plastic } \\
\text { garbage (argumentative texts). }\end{array}$ \\
\hline 9 & 7 th & $\begin{array}{l}\text { The school is surrounded by a river system that is important for the history of the } \\
\text { whole area. The students collaborated on an energy project with the inter-municipal }\end{array}$ \\
\hline
\end{tabular}




\begin{tabular}{|l|l|l|}
\hline & & $\begin{array}{l}\text { power plant, exploring the history of hydropower and how it is utilised today } \\
\text { (reports; presentations; diagrams). }\end{array}$ \\
\hline 10 & 6 th & $\begin{array}{l}\text { Students learned about the coexistence of bumblebees and plants through pollination. } \\
\text { They sowed seeds and grew bumblebee-friendly plants and learned how food } \\
\text { production is related to bees' survival throughout the world (made bumblebee nests, } \\
\text { meals). }\end{array}$ \\
\hline 11 & 7 th & $\begin{array}{l}\text { A nature area near the school was proposed as a new harbour area. The students } \\
\text { mapped its biodiversity, inhabitants' use of the area and their opinions about the } \\
\text { proposal. Students delivered a letter and a report to the municipality's leadership and } \\
\text { experienced participation in local democracy (report; roleplay; panel debate). }\end{array}$ \\
\hline 12 & 6 th & $\begin{array}{l}\text { Students found local recipes based on raw materials from the sea which are now } \\
\text { largely unutilised, and they made a cookbook. Students became familiar with topics } \\
\text { such as overfishing, unutilised resources, historical utilisation of marine resources, } \\
\text { protection of threatened species and biotopes and challenges involving } \\
\text { introduced/alien species (tables; cookbook; interviews). }\end{array}$ \\
\hline 13 & 5 th -7 th & $\begin{array}{l}\text { Based on the presence of large and small newts in several ponds in the school's local } \\
\text { environment, students learned about endangered species, mapped their habitat and } \\
\text { participated in practical initiatives to improve the biotope (report). }\end{array}$ \\
\hline 14 & 5 th -7 th & $\begin{array}{l}\text { Students assessed the social, economic and environmental consequences of macro } \\
\text { algae harvesting. Management of the kelp forest was discussed in terms of } \\
\text { sustainable principles. In addition, they looked at harvesting in its historical } \\
\text { perspective (brochure; poetry; seaweed soup). }\end{array}$ \\
\hline
\end{tabular}

\section{Results}

Based on 14 curriculum units designed for 5th-7th grade students, the study investigated the educational practices that teachers used to engage students in a multidisciplinary approach to ESD.

\section{Interdisciplinarity}

SBP curriculum units were required to adopt a multidisciplinary approach, focusing on natural science or social studies. The units included competence aims based on 3-8 subjects, and 11 schools reported 4-5 subjects (Figure 2). 


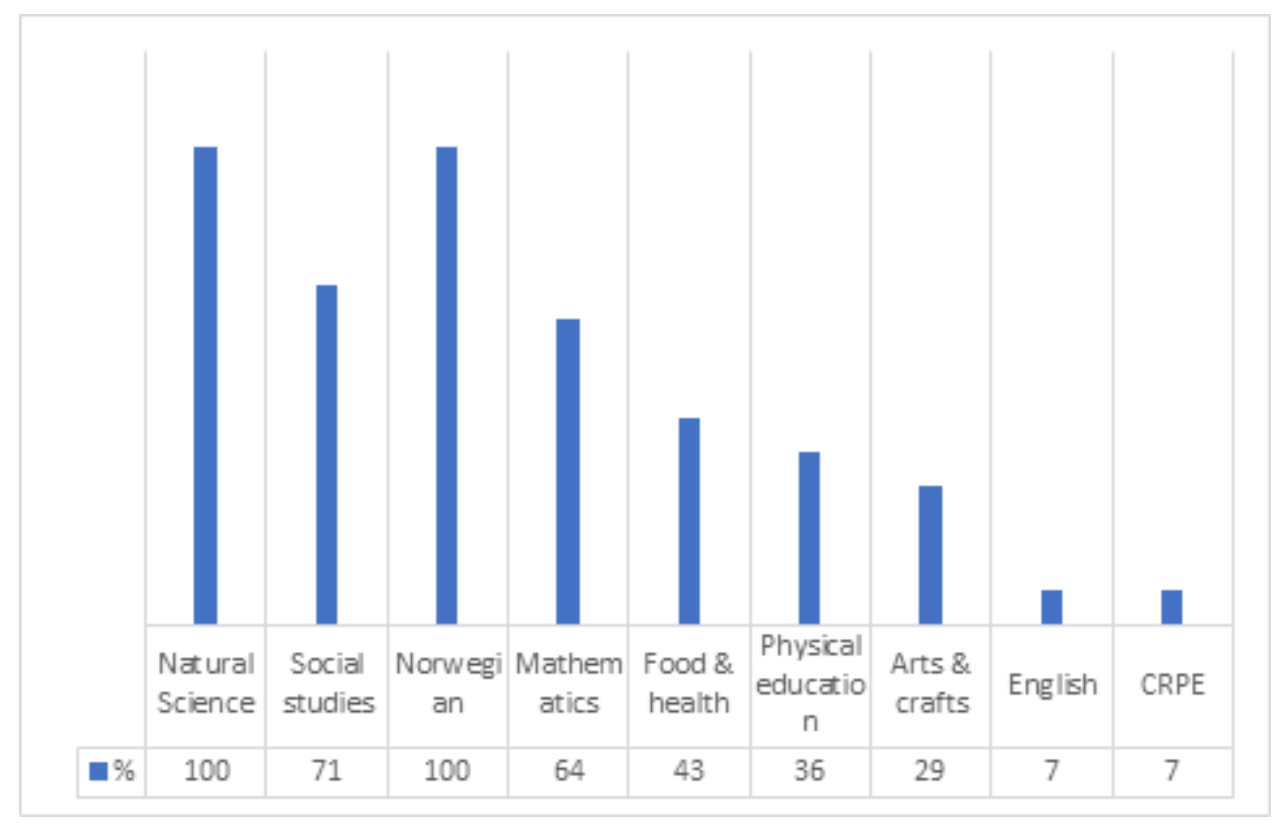

Figure 2. Subjects referred to in curriculum units.

\section{Natural Science}

All curriculum units included natural science. The first four competence aims dealt with the process dimension of science ("the budding researcher"); $71 \%$ of the schools reported competence aims involving real-world investigations (NS1), and 29\% carrying out secondary investigations (NS4, Table 3). The main subject area ("diversity in nature") had one competence aim involving investigations (NS1), and $86 \%$ of the projects included this aim (NS6, Table 3). In two units (cases 5 and 9), there was no competence aim promoting first-hand student investigations in natural science or in social studies (SS1, Table 4).

Table 3. Competence Aims for the Natural Science Subject

\begin{tabular}{|l|l|}
\hline Competence aim & Percentage (case no.; see Table 2) \\
\hline $\begin{array}{l}\text { NS1: Formulating science questions, providing explanations, } \\
\text { planning and conducting investigations. }\end{array}$ & $\begin{array}{l}71 \%(1,3,4,6,7,8,10,11,12, \\
13)\end{array}$ \\
\hline NS2: Reflecting on hypothesis testing. & $14 \%(7,8)$ \\
\hline $\begin{array}{l}\text { NS3: Using digital tools to register, prepare and publish data from } \\
\text { explorative activities. }\end{array}$ & $57 \%(1,2,3,8,9,11,12,13)$ \\
\hline $\begin{array}{l}\text { NS4: Extracting information from texts; creating presentations. } \\
\text { NS6: Planning and executing investigations in at least one nature } \\
\text { area; recording observations and systematising the results. }\end{array}$ & $\begin{array}{l}86 \%(3,4,12,14) \\
13,14)\end{array}$ \\
\hline
\end{tabular}


Note: The main subject areas are "the budding researcher" (NS1-NS5) and "diversity in nature" (NS6). Competence aim labels refer to their subject (natural science/NS) and are numbered in order of their appearance on the Directorate of Education website at https://www.udir.no/k106/NAT1-

03/Hele/Kompetansemaal/competence-aims-after-year-level-7?lplang=http://data.udir.no/kl06/eng.

Only $14 \%$ of the units included competence aims that required students to reflect on hypothesis testing (NS2, Table 3); 57\% included competence aims that promoted students' use of digital tools to record, prepare and publish data from the explorative activities (NS3, Table 3). Other natural science competence aims were related to unit topics.

\section{Social Studies}

In $71 \%$ of the curriculum units, there were competence aims related to social studies (Figure 2 ), and $21 \%$ included the aim of promoting investigations (SS1, Table 4). Three units included competence aims that promoted investigations related to both natural science and social studies (cases 4, 8, 10; Table 4).

Table 4. Competence Aims for the Social Studies Subject

\begin{tabular}{|l|l|}
\hline Competence aims & $\begin{array}{l}\text { Percentage (cases by no.; see } \\
\text { Table 2) }\end{array}$ \\
\hline $\begin{array}{l}\text { SS1: Encouraging the students to formulate questions related to social } \\
\text { studies, recommend possible explanations and illustrate questions } \\
\text { through investigation. }\end{array}$ & $21 \%(4,8,10)$ \\
\hline $\begin{array}{l}\text { SS22: Explaining how production and consumption can destroy } \\
\text { ecosystems and pollute soil, water and air and discussing and elaborating } \\
\text { on how this might be prevented and repaired. }\end{array}$ & $36 \%(4,7,9,10,12)$ \\
\hline
\end{tabular}

Note: Competence aim labels refer to their subject (social science/SS) and are numbered in order of their appearance on the Directorate of Education website at https://www.udir.no/k106/SAF103/Hele/Kompetansemaal/competence-aims-after-year-level-7?lplang=http://data.udir.no/k106/eng.

Competence aim SS22, an environment-related aim, featured in $36 \%$ of the projects. This aim and the remaining social studies competence aims (other than in the case of "the budding researcher") reflected the units' topics.

\section{The Norwegian Language Subject}

All schools worked with competence aims in the Norwegian language subject (Figure 2); aims supporting dialogical competences featured in $57 \%$ of the units. Students' presentations featured in 57\%, written text competence was emphasised by $64 \%$ of the units, 
of which 57\% promoted narrative, descriptive, reflective and argumentative writing. Table 5 summarises these aims and the relevant cases.

Table 5. Competence Aims for the Norwegian Language Subject

\begin{tabular}{|c|c|}
\hline Competence aim & $\begin{array}{l}\text { Percentage (cases by } \\
\text { no.; see Table } 2 \text { ) }\end{array}$ \\
\hline $\begin{array}{l}\text { Dialogic competences } \\
\text { N1: Listening to and developing input from others while distinguishing } \\
\text { between opinion and fact. } \\
\text { N2: Expressing and justifying one's own views while respecting the views } \\
\text { of others. } \\
\text { N5: Expressing oneself using a varied vocabulary appropriate to the } \\
\text { communication situation. } \\
\text { N7: Assessing oral presentations given by others based on professional } \\
\text { criteria. }\end{array}$ & $\begin{array}{l}43 \%(3,4,6,7,9 \\
14) \\
7 \%(8) \\
7 \%(12) \\
21 \%(3,9,14)\end{array}$ \\
\hline $\begin{array}{l}\text { Student presentations } \\
\text { N3: Using song, music and images in performances and presentations. } \\
\text { N5: Expressing oneself using a varied vocabulary appropriate to the } \\
\text { communication situation. } \\
\text { N6: Presenting professional information adapted for a given purpose and } \\
\text { recipient, with or without digital tools. } \\
\text { N7: Assessing oral presentations given by others based on professional } \\
\text { criteria. }\end{array}$ & $\begin{array}{l}29 \%(1,2,7,10) \\
7 \%(12) \\
36 \%(1,3,10,12 \\
14) \\
21 \%(3,9,14)\end{array}$ \\
\hline $\begin{array}{l}\text { Reading } \\
\text { N8: Reading a wide selection of Norwegian and translated texts in different } \\
\text { genres and reflecting on their content and form. } \\
\text { N9: Citing, summarising and reflecting on the key points in a text. } \\
\text { N11: Understanding and interpreting information from different forms of } \\
\text { expression in a composite text. } \\
\text { N19: Selecting and evaluating information from library and digital } \\
\text { information sources. } \\
\text { N29: Using different kinds of digital and paper-based dictionaries. }\end{array}$ & $\begin{array}{l}14 \%(10,13) \\
21 \%(4,10,13) \\
14 \%(9,13) \\
36 \%(1,5,8,9,13) \\
7 \%(12)\end{array}$ \\
\hline $\begin{array}{l}\text { Writing } \\
\text { N12: Form and orthography. } \\
\text { N13: Coherent and functional handwriting. } \\
\text { N14: Clearly expressed theme and coherence of sentences and paragraphs. } \\
\text { N18: Using digital sources and tools. }\end{array}$ & $\begin{array}{l}7 \%(13) \\
7 \%(7) \\
36 \%(3,4,10,12 \\
13) \\
36 \%(1,3,4,10,13)\end{array}$ \\
\hline $\begin{array}{l}\text { Text competences } \\
\text { N15: Writing narrative, descriptive, reflective and argumentative texts. } \\
\text { N17: Providing feedback on other students' texts based on professional } \\
\text { criteria and developing one's own texts based on the feedback from others. }\end{array}$ & $\begin{array}{l}57 \%(1,3,5,8,11 \\
12,13,14) \\
29 \%(1,4,8,13)\end{array}$ \\
\hline
\end{tabular}

Note: Competence aim labels refer to their subject (Norwegian/NO) and are numbered in order of their appearance on the Directorate of Education website at https://www.udir.no/k106/NOR105/Hele/Kompetansemaal/competence-aims-after-year-7?lplang=http://data.udir.no/k106/eng. 


\section{Other Subjects}

In the $64 \%$ of units that included mathematics (Figure 2), competence aims were related to measurements and estimates (21\%), collecting data (43\%) and use of figures and diagrams when presenting results, as well as competence in interpreting figures and diagrams (43\%). Of the $43 \%$ of units that included food and health, $29 \%$ focused on developing a product from natural resources.

Art and crafts featured in $29 \%$ of the curriculum units, physical education in $36 \%$, English in $7 \%$ and Christianity, religion, philosophy of life and ethics (CRPE) in 7\%. The only competence aim of CRPE is to get students talking about relevant philosophical and ethical questions, discussing challenges related to poverty and wealth, war and peace, nature and environment and Information and communications technology and society.

\section{Teachers' Perceptions of Teaching Outcome Related to the Three Dimensions of SD}

In their reports, all schools referred to student activities or learning outcomes linked to both the environmental and the social dimension (Table 6, example items 1-3).

Table 6. Excerpts from Curriculum Unit Reports about Students' Outcome Related to the Three Dimensions of SD

\begin{tabular}{|l|l|}
\hline $\begin{array}{l}\text { Excerpt } \\
\text { no. }\end{array}$ & Excerpt from the curriculum unit report \\
\hline 1 & $\begin{array}{l}\text { "... The students have gained knowledge about the local river and how people influence it. They } \\
\text { conducted a survey about what the river means personally for their family members and for the } \\
\text { local community in general." }\end{array}$ \\
\hline 2 & $\begin{array}{l}\text { "... Pupils explore and learn about the importance of water and its power for settlement and jobs } \\
\text { throughout the ages. The large rivers and waterfalls have been important for the area, both as } \\
\text { power sources and as habitats for animals such as frogs and fish. The pupils also worked to adapt } \\
\text { consumption to a sustainable way of life." }\end{array}$ \\
\hline 3 & $\begin{array}{l}\text { “...By visiting these nature areas students learned more about biological diversity and the } \\
\text { fragility of living creatures in this harsh environment. They also investigated regulations and } \\
\text { restrictions in similar areas in Russia and Finland. The work on this project has helped to } \\
\text { highlight the need for special protection for specified natural areas and puts this into a social } \\
\text { context." }\end{array}$ \\
\hline 4 & $\begin{array}{l}\text { "The students assessed the prices of products with different forms of packaging." } \\
\text { "The economic dimension was highlighted when one of the landowners wanted a parking area } \\
\text { instead of a newt pond." }\end{array}$ \\
\hline 5
\end{tabular}


The economic perspective appears in only half of the units. One unit described what the students had done (example item 4), but in the other six units, descriptions were very general (example item 5).

\section{Discussion}

\section{Interdisciplinarity}

McKeown and Hopkins (2003) claimed that every subject can contribute to ESD by providing knowledge, skills, perspectives and values. They exemplified this through the fact that mathematics can help to understand very small numbers (ppb/parts per trillion), history can help to see things change over time, social sciences and natural science can help to understand various environmental problems and the language subject can encourage students to become literate in encounters with, for example, media. They made the reservation that not all teachers have the necessary competence at ESD and stated the importance of competent teachers being given the necessary mandate and resources to accomplish to educate students for sustainability in the future. Together, the subjects create a holistic approach to ESD. Many attempts have been made to overcome the traditional teaching approach, whereby the subjects are taught separately, by emphasising a holistic approach (Root-Bernstein, 2018).

This study has looked at what subjects and what competence aims teachers include in their ESD teaching programs. It followed up on the earlier recommendations in relation to ESD projects to explore how different subjects combine to teach sustainability and the teachers' perceptions of how their curriculum units promote the environmental, social and economic dimensions of SD in Norwegian classrooms. However, the study does not deeply say anything about how the different subjects are blended into each other or about teachers' collaboration across subject boundaries.

The schools had to include natural science or social studies in their teaching units. All included natural science, while $71 \%$ included Social studies. All unit topics were linked to the local community through natural science - for instance, through local species, local nature areas or the cultivation of different crops. When social sciences were included, it involved studies of societal relationships in relation to natural science issues. Ichinose (2017) also found that ESD teaching was linked to the local community and that the 
expected outcome for the students was love for and pride of their local district. Knowledge of the cultural heritage of a local community, such as traditional knowledge and local names of plants and animals, may be the basis for the cultural identity of the inhabitants (Tunón, 2012, in Munkebye \& Fiskum, 2014). Much of our cultural identity, both nationally and locally, is linked to nature and natural products and generations' knowledge of them. By strengthening the cultural identity, one can also strengthen the individuals' desire to protect nature as developing closeness by becoming part of one's self (Tunòn \& Dahlström, 2010, in Munkebye \& Fiskum, 2014). Knowledge of plant and animal species, interest in nature and nature experiences have been found to be factors that increase the commitment to sustainable development and conservation of biodiversity (Kvammen \& Munkebye, 2018; Lindemann-Matthies, 2006; Palmberg \& Kuru, 2000). Conservation of biodiversity can be used as local authentic conflicts of interest, in Norwegian classrooms, as the country continue to develop renewable energy sources, as this adversely affects natural areas, ecosystem and biodiversity.

It is traditional among Norwegian science teachers to view environmental education (EE) as part of their responsibility. This is not surprising, as Borg and colleagues (2012) found that ESD is still seen in schools as EE. In the Norwegian curricula, both EE and to a lesser extent ESD are seen as part of natural science, and science teachers therefore assume the responsibility for the ESD school projects. However, ESD is also a central element of social studies curricula, and it is important to note that the choice of natural science may also have been influenced by the content of the capacity building programme. The SBP is run by the Norwegian Centre for Science Education, and there are more science educators involved in the resource group than pedagogy and social studies educators.

Curriculum units included competence aims that promote students' investigations into both natural science (NS1, NS6) and social studies (SS1), except for two projects that involved neither primary nor secondary investigation (of texts; cases 5 and 9). However, their aims supported investigations in relation to the use of digital tools for inquiry (NS3) as well as measurements in mathematics, data collection and the use of diagrams when presenting results (M12, M14, M19). The Norwegian language subject also supported investigations as students wrote texts (NO15) and made presentations (NO5, NO6, NO7) about their inquiries, confirming that the subjects are integrated. The integration of subjects like natural science, social studies and Norwegian in these curriculum units may indicate that students 
achieve a more holistic and deeper understanding of SD (Stables \& Scott, 2002; Boeve-de Pauw, Gericke, Olsson, \& Berglund, 2015). The distribution of natural science, social studies and the Norwegian language subject are largely related to their distribution in similar curriculum units for students aged between 6 and 9 years (Munkebye, 2016). The SBP encourages teachers to use an exploratory approach, with an emphasis on student activity. This may explain the great emphasis on competence goals within the main areas of "the budding scientist" and "the researcher." This emphasis highlights the inquiry approach as a good way to integrate the various subjects.

The curriculum includes some aims that challenge students more than others, and these featured less in the curriculum units. Natural science's main area ("the budding scientist") includes one aim promoting reflection on hypothesis testing (NS2). Social studies main area ("the researcher") includes one aim that encourages students to respect others' views, use relevant vocabulary and distinguish between opinions and facts (SS2). Only two curriculum units included these aims.

We argue that there is untapped potential in CRPE, where students are expected to discuss current philosophical and ethical issues, challenges related to issues such as poverty and wealth, war and peace and nature and the environment (CRPE40) and time-related value issues of concern to the Sami indigenous peoples (CRPE42) and to explain important parts of the UN Universal Declaration of Human Rights and its importance (CRPE46). Only one curriculum unit included the CRPE40 aim. However, we must remain open to the possibility that these aims were included to some extent but were omitted from the teachers' reports.

In the case of the Norwegian language subject, there also is evidence of untapped potential. Being able to communicate, participate and interact are emphasised as important competences in the context of the school and ESD (Kunnskapsdepartementet, 2015; UNESCO, 2017). To be dialogically competent includes being able to reason and analyse, to identify relevant questions and to assess claims, arguments and evidence. These are important competencies when dealing with complex issues related to SD (Kunnskapsdepartementet, 2015; UNESCO, 2017). Here, the curriculum units to some extent addressed the aim of promoting students' dialogic listening competence (N1), but only two curriculum units featured aims related to students' ability to express themselves in terms of explaining their personal views (N2, case 8) and using language appropriate to the situation (N5, case 12). In $57 \%$ of cases, aims related to writing narrative, descriptive, 
reflective and argumentative texts were included. Given the different types of text, it is difficult to know exactly what the units may have emphasised.

Looking at the curriculum for students aged 10-13, there seems to be little emphasis on the aims promoting argumentation and reflection that might be appropriate to ESD curriculum units, other than CRPE. Aguilar (2018) found students' reflections on social institutions and power dynamics to be important for EE/ESD programs to meet their goals. However, in the Norwegian language subject, there are aims that promote argumentation. When these aims are integrated with aims in natural science or social studies, there are opportunities to challenge students to a greater extent in argumentation about SD. There may be a concern that curriculum units do not have competence aims that are more cognitively challenging. In her review article, Tilbury (2011) has identified essential ESD learning processes that encourage students, among other things, to be critical. Focusing on telling, referring, listening and summarising rather than discussing, reflecting, arguing and comparing does not promote the students' critical approach to the extent that it could have been promoted.

We cannot ignore the fact that a lack of emphasis on more cognitively challenging competence aims may be due to teachers finding that the time they can spend on ESD is limited by a comprehensive curriculum with many aims to be achieved during the school year. Substance congestion in schools is experienced as an obstacle to in-depth learning, understood as opposite to surface learning (Kunnskapsdepartementet, 2014). This is in line with international research showing that a lack of time can be a barrier to implementing ESD in schools (Borg et al., 2012; Pepper \& Wildy, 2008; Corney, 2006; Guisasola, Robinson, \& Zuza, 2007; Oulton et al., 2004; Summers, Corney, \& Childs, 2003). Furthermore, evaluations of the Knowledge Promotion Reform in Norway have shown that the schools have worked less with interdisciplinary themes than earlier years. It has been shown that schools' priorities have been on competence aims in the subject curriculum and on basic skills rather than on holistic and interdisciplinary work (Imsen \& Ramberg, 2014).

\section{Teachers'Perceptions of Teaching Outcome Related to the Three Dimensions of SD}

In their educational framework based on analyses of selected ESD programs, Eilam and Trop (2011) presented interdisciplinary learning as one of the four essential components needed to achieve the ESD objectives. Interdisciplinarity support system, understanding and the linkages between cause and effect within systems are important elements for in-depth 
knowledge in ESD (Breiting, Mayer, \& Mogensen, 2005; Fine \& Tilbury, 2002). If we could see our own unsustainable way of living as part of a larger system, it might encourage us to act for sustainability. Senge (1991) claimed that "observed processes [extinction of species] are naturally composed of many interconnected components which ought to be studied jointly rather than individually" (p. 1), through systems thinking. Kordova et al.'s (2018) study of higher education showed that students find systems thinking complicated, making it necessary to create systems thinking study course that deal with specific methodologies and systems thinking tools. Initially, SD was defined to consist of three intertwined dimensions with a relationship in time and space, requiring a holistic approach (Wals, 2012). This indicates that teachers face major challenges as they must be able to think holistically themselves and be able to facilitate students' holistic thinking in ESD. In practice, many teachers face multiple challenges when teaching SD in particular because SD is an interdisciplinary topic, in contrast to school subjects which are generally monodisciplinary. (Borg, 2011; Borg et al., 2012; Pharo et al., 2012; Wolff, Sjöblom, Hofman-Bergholm, \& Palmberg, 2017)

The present findings indicate that the teachers developed curriculum units for ESD that focused mainly on the environmental and social dimensions of sustainability. Using an interdisciplinary approach, these school projects pursued their themes from a social and environmental perspective. On closer examination of the teachers' reports and students' products, it became evident that the inclusion of the economic aspect of SD was poor when planning the units. Looking at the seven projects that claimed to address economic issues, we found this to be true only at a very general and vague level. This finding aligns with other evidence that teachers find it difficult to integrate the three dimensions in their own understanding and teaching (Borg, Gericke, Høglund, \& Bergman, 2014; Giddings, Hopwood, \& O'Brien, 2002). Summers and Childs (2007) found that among newly educated natural science secondary teachers, only $15 \%$ highlighted all three dimensions, with the centrality of the environmental, social and economic dimensions being $72 \%, 49 \%$ and $53 \%$, respectively. Pepper and Wildy (2008) found that Australian secondary teachers only focused on the environmental dimension. Kopnina $(2012,2014)$ argued that a pluralistic and holistic approach can lead teachers into an anthropocentric approach to ESD, whereby the socio-economic perspective takes the focus away from the challenges facing the environment, which does not appear to be the case in this study. 
Research also shows that many teachers and student teachers feel that they do not have the necessary skills to teach controversial topics (Corney, 2006; Oulton et al., 2004; Summers, Childs, \& Corney, 2005). If teachers are to increase ESD competence, it is important that they are qualified for this in their teacher education or through teachers' professional development. However, research indicates that Finnish teacher educators do not have the competence to see the whole system using the three dimensions of SD and do not prepare teacher students for ESD (Hofman-Bergholm, 2012; Hofman-Bergholm, 2018; Wolff et al., 2017). Unfortunately, we lack Norwegian research in this field.

All curriculum units in this study can be categorised as for learning SD (ESD1; Vare \& Scott, 2007). The students acquired knowledge about environmental challenges and performed expert knowledge-driven sustainability-friendly actions. Vare and Scott (2011) described the second loop as complementary to the first and which they described to be learning as SD (ESD2). Unlike the first loop, ESD1, this loop is a continuous process that prepares students to meet current as well as future environmental challenges. ESD2 does not rest on expert knowledge but qualifies students to relate critically to the outside world. Several of the teaching units can be categorised as learning as SD because they enhance student empowerment, motivation and critical attitude. This can be exemplified through case 11, where the students gained experience in evaluating different solutions. Students were allowed to present their arguments in the City Hall, and their involvement was mentioned in the local newspaper.

\section{Conclusion}

We can conclude that schools' approach to sustainable development is to some extent holistic. Regarding the three dimensions of SD, the curriculum units emphasised and linked the environmental and social dimensions, focusing less on the economic dimension. While the curriculum units applied several subjects to SD, there is untapped potential, especially in CRPE and the Norwegian language subject, where teachers could have challenged the students' reflection to a greater extent. This study does not address all the factors that define a holistic perspective (see Borg et al., 2014; Boeve-de Pauw et al., 2015) as it omits issues such as local, regional and global approaches and different time perspectives.

Based on the results, we have further developed our work with teachers implementing ESD through the SBP. In collaboration with teacher teams, we have directed attention to the 
unused potential of different subjects in terms of exploration, argumentation, critical thinking and ethical issues. To encourage a more pluralistic approach to teaching, we have introduced wicked problems, placing emphasis on students' argumentation and critical skills (Scheie \& Stromholt, 2019).

As noted by Summers and Corney (2005) and Borg et al. (2012), teachers lack the necessary expertise to teach ESD, as confirmed by our own experience in this area since 2009. The SBP enables teachers to network and to discuss ESD. Building on this study, we have developed didactic models for teaching beyond the curriculum to help teachers to prepare and implement SD-related teaching sequences and projects in the classroom.

Acknowledgements

We want to thank the teachers who developed the curriculum units and shared them with us.

\section{References}

Aguilar, O. M. (2018). Examining the literature to reveal the nature of community EE/ESD programs and research. Environmental Education Research, 24(1), 26-49.

Boeve-de Pauw, J., Gericke, N., Olsson, D., \& Berglund T. (2015). The effectiveness of education for sustainable development. Sustainability, 7(11), 15693-15717.

Boix-Mansilla, V., \& Duraisingh, E. D. (2007). Targeted assessment of students' interdisciplinary work: An empirically grounded framework proposed. The Journal of Higher Education, 78(2), 215-237.

Borg, C. (2011). Utbildning för hållbar utveckling ur ett lärarperspektiv: Ämnesbundna skillnader i gymnasieskolan.[ Education for sustainable development from a teacher's perspective: Subject-specific differences in upper secondary school]. Doctoral dissertation, Karlstad University, Sweden.

Borg, C., Gericke, N., Höglund, H.-O. \&, Bergman, E. (2012). The barriers encountered by teachers implementing education for sustainable development: Discipline bound differences and teaching traditions. Research in Science and Technological Education, 30(2), 185-207.

Borg, C., Gericke, N., Höglund, H.-O. \&, Bergman, E. (2014). Subject- and experiencebound differences in teachers' conceptual understanding of sustainable development. Environmental Education Research, 20(4), 526-551.

Breiting, S., Mayer, M., \& Mogensen, F. (2005). Quality criteria for ESD-schools: Guidelines to enhance the quality of education for sustainable development. Vienna: ENSI. 
Castleberry, A., \& Nolen, A. (2018). Thematic analysis of qualitative research data: Is it as easy as it sounds? Currents in Pharmacy Teaching and Learning, 10(6), 807-815.

Corney, G. (2006). Education for sustainable development: An empirical study of the tensions and challenges faced by geography student teachers. International Research in Geographical and Environmental Education, 15(3), 224-40.

Creswell, J. W. (1998). Qualitative inquiry and research design: Choosing among five traditions. Thousand Oaks,CA:Sage Publications.

Dale, A., \& Newman, L. (2005). Sustainable development, education and literacy. International Journal of Sustainability in Higher Education, 6(4), 351-362.

De Haan, G. (2006). The BLK '21' programme in Germany: A 'Gestaltungskompetenz'based model for education for sustainable development. Environmental Education Research, 12(1), 19-32.

Eilam, E., \& Trop, T. (2011). ESD pedagogy: A guide for the perplexed. The Journal of Environmental Education, 42(1), 43-64.

Fien, J., \& Tilbury, D. (2002). The global challenge of sustainability. Education and sustainability. In Tilbury, D., Stevenson, R. B., Fien, J. \& Schreuder, D. (Eds.), Education of sustainability: Responding to the global challenge (pp. 1-12). Commission on Education and Communication, Geneva: IUCN

Gayford, C. (2002). Controversial environmental issues: A case study for the professional development of science teachers. International Journal of Science Education, 24(11), 1191-1200.

Giddings, B., Hopwood, B., \& O’Brien, G. (2002). Environment, economy and society: Fitting them together into sustainable development. Sustainable Development, 10, 187-196.

Guisasola, J., Robinson, M., \& Zuza, K. (2007). A comparison of the attitudes of Spanish and American secondary science teachers toward global science and technologybased problems/threats. Journal of Environmental and Science Education, 2(1), 2031.

Hodgson, J., Rønning, W., \& Tomlinson, P. (2012). Sammenhengen mellom undervisning og laring. En studie av lareres praksis og deres tenkning under Kunnskapsløftet. Retrieved from http://www.nordlandsforskning.no/getfile.php/1324031412587174/Dokumenter/Rapporter/2012/Rapport 04 2012.pdf

Hofman, M. (2012). Hållbar utveckling i den finländska lärarutbildningen—politisk retorik eller verklighet? [Sustainable development in Finnish teacher education-Political rhetoric or reality?] (Report no. 34). Vaasa, Finland: Åbo Akademi University.

Hofman-Bergholm, M. (2018). Changes in thoughts and actions as requirements for a sustainable future: A review of recent research on the Finnish educational system and sustainable development. Journal of Teacher Education for Sustainability, 20(2), 19-30. 
Ichinose, T. (2017). An analysis of transformation of teaching and learning of Japanese schools that significantly addressed education for sustainable development. Journal of Teacher Education for Sustainability, 19(2), 36-50.

Imsen, G., \& Ramberg, M. R. (2014). Fra progressivisme til tradisjonalisme i den norske grunnskolen? [From progressivism to traditionalism in the Norwegian elementary school?] Sosiologi i dag, 44(4), 10-35.

Kopnina, H. (2012). Education for sustainable development (ESD): The turn away from 'environment' in environmental education? Environmental Education Research, 18(5), 699-717.

Kopnina, H. (2014). Revisiting education for sustainable development (ESD): Examining anthropocentric bias through the transition of environmental education to ESD. Sustainable development, 22(2), 73-83.

Koppelman, J. (2010). Are we really educating about sustainability? Journal of Sustainability Education, 5. Retrieved from http://www.jsedimensions.org/wordpress/wp-content/uploads/2013/05/JustinKoppleman-May2013finalproof.pdf

Kordova, S., Frank, M., \& Nissel Miller, A. (2018). Systems thinking education-Seeing the forest through the trees. Systems, 6(3), 29.

Kunnskapsdepartement. (2012). Kunnskap for en felles framtid: Revidert strategi for utdanning for barekraftig utvikling 2012-2015. [Knowledge for a common future: Revised strategy for education for sustainable development 2012-2015]. Retrieved from https://www.regjeringen.no/globalassets/upload/kd/vedlegg/uh/rapporter_og_planer/ strategi_for_ubu.pdf

Kunnskapsdepartementet (2014). Elevenes laring i fremtidens skole-et kunnskapsgrunnlag. [Students' learning in the school of the future - a knowledge base]. Retrieved from https://www.regjeringen.no/contentassets/e22a715fa374474581a8c58288edc161/no/ pdfs/nou201420140007000dddpdfs.pdf

Kunnskapsdepartement. (2015). Fremtidens skole: Fornyelse av fag og kompetanser. [School of the Future: Renewal of subjects and competences]. Retrieved from https://www.regjeringen.no/contentassets/da148fec8c4a4ab88daa8b677a700292/no/ pdfs/nou201520150008000dddpdfs.pdf

Kunnskapsdepartementet. (2016). Overordnet del-verdier og prinsipper for grunnopplaringen. [ Core curriculum - values and principles of primary and secondary education]. Retrieved from https://www.regjeringen.no/contentassets/53d21ea2bc3a4202b86b83cfe82da93e/ove rordnet-del---verdier-og-prinsipper-for-grunnopplaringen.pdf

Kvammen, P. I., \& Munkebye, E. (2018). Artskunnskap som introduksjon til naturfag i grunnskolelærerutdanningen [Knowledge about species and field work-Evaluation of a teaching program]. Nordic Studies in Science Education, 14(4), 381-394. 
Lindemann-Matthies, P. (2006). Investigating nature on the way to school: Responses to an educational programme by teachers and their pupils. International Journal of Science Education, 28(8), 895-918.

L97. (1996). Laereplanverket for den 10-årige grunnskolen. [Curriculum for the 10-year primary school]. Oslo, Norway: Kirke-, utdannings- og forskningsdepartementet.

McKeown, R., \& Hopkins, C. (2003). EE p ESD: Defusing the worry. Environmental Education Research, 9(1), 117-128.

Munkebye, E. (2016). Implementation of education for sustainable development in primary schools-In a Norwegian perspective. In L. Tuszynska (Ed.), Environmental education for sustainable development in teacher education (pp. 67-82). Warszawa, Poland: Maria Grzegorzewska University.

Munkebye, E., \& Fiskum, T. (2014). Tidligere bruk og oppfattelse av natur - en ressurs i dagens skole. [Traditional use and perception of nature - a resource in today's school.]. In T. Fiskum \& J. A. Husby (Eds.). Uteskoledidaktikk: ta fagene med ut [Outdoor school didactics: take the subjects out (]. (pp. 163-176). Oslo, Norway: Cappelen Damms forlag.

Oulton, C., Day, V., Dillon, J., \& Grace, M. (2004). Controversial issues: Teachers' attitudes and practices in the context of citizenship education. Oxford Review of Education 30(4), 489-507.

Palmberg, I. E., \& Kuru, J. (2000). Outdoor activities as a basis for environmental responsibility. The Journal of Environmental Education, 31(4), 32-36.

Pepper, C., \& Wildy, H. (2008). Leading for sustainability: Is surface understanding enough? Journal of Educational Administration, 46(5), 613-629.

Pharo, E., A. Davison, K., Warr, M., Nursey-Bray, K., Beswick, E., Wapstra, \& Jones, C. (2012). Can teacher collaboration overcome barriers to interdisciplinary learning in a disciplinary university? A case study using climate change. Teaching in Higher Education, 17(5), 497-507.

Rickinson, M., Lundholm, C., \& Hopwood, N. (2009). What is environmental learning? Environmental learning (pp. 11-21). Dordrecht, Netherlands: Springer.

Robson, C. (2002). Real world research: A resource for social scientists and practitionerresearchers. Oxford, UK: Blackwell.

Root-Bernstein, R. (2018). STEMM education should get "HACD." Science, 361(6397), 22-23. doi: 10.1126/science.aat8566

Scheie, E., \& Stromholt, S. (2019). “The Sustainable Backpack": Exploring possibilities in education for sustainable development through a nationwide professional development program. Acta Didactica Norge, 13(2). Retrieved from https://doi.org/10.5617/adno.6473

Senge, P. M. (1999). The fifth discipline fieldbook: Strategies and tools for building a learning organization. New York, NY: Bantam Doubleday Dell Publishing Group. 
Sjaastad, J., Carlsten, T. C., Opheim, V., \& Jensen, F. (2014). Evaluering av Den naturlige skolesekken: Utdanning for barekraftig utvikling på ulike laringsarenaer.

[Evaluation of the Sustainable Backpack: Education for Sustainable Development in Different Learning Areas] NIFU-rapport 2014:38. Oslo: NIFU.

Sjøberg, S., Jorde, D., Haldorsen, K., \& Lea, A. (1995). Naturfagutredningen [Report on science in school]. Oslo, Norway Norwegian Ministry of Education, Research and Church Affairs, and University of Oslo.

Solstad, K. J., Rønning, W., \& Karlsen, E. (2003). Tema og prosjektarbeid og bruk av larestoff etter L97. [Theme and project work and use of teaching material after L97.] Sluttrapport fra prosjektet 'Likeverdig skole i praksis'. NF-rapport 24. Bodø, Norway: Nordlandsforskning. Retrieved from http://www.nordlandsforskning.no/getfile.php/1331051412773993/Dokumenter/Rapporter/2003/rapp_24_03.pdf

Stables, A., \& Scott W. (2002). The quest for holism in education for sustainable development. Environmental Education Research, 8(1), 53-60.

Stake, R. E. (1995). The art of case study research. Thousand Oaks, CA: Sage.

Statistics Norway. (2020). External trade in goods. Retrieved from https://www.ssb.no/en/muh/.

Summers, M., Corney, G., \& Childs, A. (2003). Teaching sustainable development in primary schools: An empirical study of issues for teachers. Environmental Education Research 9(3), 327-46.

Summers, M., Childs, A., \& Corney, G. (2005). Education for sustainable development in initial teacher training: Issues for interdisciplinary collaboration. Environmental Education Research, 11(5), 623-647.

Summers, M., \& Childs, A. (2007). Student science teachers' conceptions of sustainable development: An empirical study of three postgraduate training cohorts. Research in Science and Technological Education, 25(3), 307-327.

Tilbury, D. (2011). Higher education for sustainability: A global overview of commitment and progress. Higher Education in the World, 4(1), 18-28.

UNESCO. (2005). United Nations Decade of Education for Sustainable Development (2005-2014): International implementation scheme. Retrieved from https://unesdoc.unesco.org/ark:/48223/pf0000139937

UNESCO. (2006). Framework for the UN DESD international implementation scheme. Paris, France: UNESCO. Retrieved from https://unesdoc.unesco.org/ark:/48223/pf0000148650

UNESCO (2014). Roadmap for implementing the Global Action Programme on education for sustainable development. Retrieved from http://unesdoc.unesco.org/images/0023/002305/230514e.pdf 
UNESCO. (2017). Education for sustainable development goals: Learning objectives. Retrieved from https://unesdoc.unesco.org/ark:/48223/pf0000247444

Utdanningsdirektoratet. (2006). Barekraftig utvikling. Utdanning for barekraftig utvikling (2006-2010). [Sustainable development. Education for sustainable development (2006-2010)]. Retrieved from https://www.miljolare.no/info/Barekraftig_utvikl_rapp.pdf

Van den Bergh, J., Atkinson, G., Dietz, S., \& Neumayer, E. (2007). Handbook of sustainable development. Cheltenham, UK: Edward Elgar.

Vare, P., \& Scott, W. (2007). Learning for a change: Exploring the relationship between education and sustainable development. Journal of Education for Sustainable Development, 1(2), 191-198.

Vibe, N. (2012). Spфrsmål til Skole-Norge 2011: Resultater og analyser fra

Utdanningsdirektoratets spфrreundersфkelse blant skoler og skoleeiere. [Questions to School-Norway 2011: Results and analyzes from the Directorate of Education's survey of schools and school owners]. (Rapport 5). Oslo, Norway: NIFU.

Wals, A. E. (2012). Shaping the education of tomorrow: Report on the UN Decade of Education for Sustainable Development. Retrieved from https://unesdoc.unesco.org/ark:/48223/pf0000216606

World Commission on Environment and Development (WCED). (1987). Our common future. A report from the United Nations World Commission on environment and development. Oxford, UK: Oxford University Press.

Wolff, L. A., Sjöblom, P., Hofman-Bergholm, M., \& Palmberg, I. (2017). High performance education fails in sustainability? - A reflection on Finnish primary teacher education. Education Sciences, 7(1), 32.

Yin, R. K. (2003). Applications of case study research. Thousand Oaks, CA: Sage Publications. 